\title{
CHANGES IN MICROBIAL POPULATION DURING MYCOREMEDIATION OF DIESEL OIL CONTAMINATED SOIL
}

\author{
*Idowu, F. C. and Ijah U.J.J. \\ Department of Microbiology, Federal University of Technology Minna, Nigeria \\ *Author for correspondence: e-mail- arabambicaroline@gmail.com; Tel.234-07037063073 \\ (Received: $29^{\text {th }}$ December, 2017; Accepted: $18^{\text {th }}$ May, 2018)
}

ABSTRACT

\begin{abstract}
The rates of bioremediation of diesel oil-contaminated soil were studied for a period of 12 weeks through changes in microbial population. Two kilograms of soil moistened with $10 \%$ distilled water (w/v) was mixed thoroughly with diesel oil (5 and 10\% concentrations respectively), and $3.6 \times 10^{6} \mathrm{ml}$ spores of each fungal consortium were inoculated in the soil and exposed to natural conditions in the field for three months. Two controls without fungal inoculants were set up: C1OS (oil + soil-control 1), and C2OS (soil only-control 2). The results revealed that the populations of diesel oil utilizing microorganisms were higher at both 5 and $10 \%$ diesel oil pollution in the three soil amendments compared to the unamended control soil. The bacterial isolates were identified as species of Pseudomonas, Bacillus, Micrococcus, Staphylococcus and Escherichia, while the fungal isolates were identified as species of Aspergillus, Scopuloropsis, Cephalosporium, Penicilluim, Geotrichum, Mucor, Trichophyton and Microsporum. The pH (5.02-6.18) of the amended soil was lower compared to the unamended control soil (5.01 6.49) after 12 weeks. The moisture content of the amended soil (10.09 to $16.42 \%)$ was higher compared to the unamended control soil (8.14 to $11.39 \%$ ) after 12 weeks. The results suggest that the isolates identified utilized the diesel oil as sources of carbon and nitrogen to proliferate.
\end{abstract}

Keywords: Bioremediation, Consortium, Contaminated, Mycoremediation, Soil

\section{INTRODUCTION}

The improper disposal, misuse and accidental release of petroleum and petroleum products into the environment, have resulted in a wide spread pollution of the soil, groundwater and the marine environment. Oil spills and oil wastes discharged into the environment contain poisonous compounds that are potential danger to plants and animals (RHF, 2012). The poisons can pass through the food chain of an area and may eventually be eaten by man. Hydrocarbons are biopersistent, bioaccumulative and can cause deleterious effects to aquatic fauna and flora as well as to humans (Norton, 2012). The degree of contamination both on land and in water through long term disregard for the environment has been devastating, altering the ecological balance and soil fertility. No matter how small, pollution influences the natural microbial community and affects both physical and chemical properties of the environment in question (Ijah and Antai, 2003). Therefore, the removal of such contamination from soil and water becomes necessary.

Diesel in general is any liquid fuel used in diesel engines. Diesel fuel is produced from petroleum and from various other sources. Petroleum diesel, also called petro diesel, or fossil diesel is produced from the fractional distillation of crude oil between $200{ }^{\circ} \mathrm{C}$ and $350{ }^{\circ} \mathrm{C}$ at atmospheric pressure, resulting in a mixture of carbon chains that typically contain between 8 and 21 carbon atoms per molecule (Collins, 2007). Petroleumderived diesel is composed of about $75 \%$ saturated hydrocarbons (primarily paraffin including, iso, and cycloparaffins), and 25\% aromatic hydrocarbons (including naphthalene and alkyl benzenes). The average chemical formula for common diesel fuel is $\mathrm{C}_{12} \mathrm{H}_{23}$, ranging approximately from $\mathrm{C}_{10} \mathrm{H}_{20}$ to $\mathrm{C}_{15} \mathrm{H}_{28}$.

Bioremediation, which is the application of biological treatment to clean up hazardous chemicals in soils and groundwater is a preferred method for decontaminating oil polluted environments, compared with the traditional methods which involve burning of oil with fire or use of chemicals and detergents to emulsify the oil, which may result in groundwater contamination and may harm the normal biota of the environment being treated (Hidayat et al., 2012). The advantages of bioremediation include inexpensive equipment, environmentally friendly nature of the process and simplicity (Norton, 
2012). However, one disadvantage of this process is that it is a slow process (Hidayat et al., 2012).

Bioaugmentation and biostimulation are methods of bioremediation used in enhancing the process. Bioaugmentation is the addition of external microbial populations, which could be indigenous or exogenous, to the oil polluted area. Sometimes, they can be genetically engineered. Biostimulation involves the addition of appropriate microbial nutrient to the polluted environment. These may either occur in-situ or ex-situ.

Considering the increasing rates of oil spills in Nigeria especially in oil producing area, many alternative cleanup methods should be encouraged. Inorganic fertilizer, chicken droppings and periwinkle shells have been employed to remediate oil polluted soil (Ijah and Antai, 2003). Agricultural wastes such as groundnut shells, rice husk, and maize cob also have been used to restore oil-spilled soils (Abioye et al., 2010).

\section{Materials and Methods \\ Collection and Processing of Soil Samples}

Crude oil polluted soil samples from oil spill site were collected at Eleme, Rivers State, Nigeria, and transported to the laboratory in the Department of Microbiology Federal University of Technology, Minna for isolation of fungi. Crude oil-free (uncontaminated) soil was also collected from a garden at Pago, Minna, Niger State, Nigeria and taken to the botanical garden of the Federal University of Technology Minna, Nigeria. The oil-free (uncontaminated) soil sample was air dried and put through a sieve with $2 \mathrm{~mm}$ mesh size and was used for bioremediation studies. Diesel oil was collected in a clean jerry can from petroleum products filling station at Bosso, Niger State, Nigeria.

\section{Utilization of Diesel Oil by Fungal Isolates}

The ability of the fungal isolates to grow on, and utilize diesel oil, as a source of carbon and energy was determined using the dry weight method of $\mathrm{Li}$ and Mira (2010). This was done by inoculating 0.1 $\mathrm{ml}$ of fungal spores $\left(1.2 \times 10^{4}\right.$ spores $)$ into $10 \mathrm{ml}$ of Bushnell and Hass (1941) medium (BHM) and $1 \%(\mathrm{v} / \mathrm{v})$ of diesel oil contained in test tubes. Control experiments were set up in test tubes containing $10 \mathrm{ml}$ of $\mathrm{BHM}$ plus $1 \%$ (v/v) of diesel oil, but without added organisms. The tubes were incubated at room temperature $\left(28 \pm 2{ }^{\circ} \mathrm{C}\right)$ for 14 days under a stationary condition. At the end of the incubation period, the growth of the inocula was determined by removing the growth, rinsed it with diethylether to remove the remaining oil. It was put in crucible that has been weighed and then weighed again to determine the weight of the crucible and the organism before drying. It was then dried in an oven at $150{ }^{\circ} \mathrm{C}$ for one hour after which the weight of the dried cells and the crucible was again determined. The weight of the cell was obtained by subtracting the weight of the crucible from the weight of the crucible plus dried cell. The extent of degradation of the incorporated diesel oil by the fungal isolates was determined by the gravimetric analysis method of Ijah and Antai (2003).

\section{Preparation of Fungal Consortium}

Three consortia were formed from fungal isolates that utilized the diesel oil at maximum rate. The first consortium had Aspergillus niger A3 and Aspergillus flavus C1. The second consortium contained Aspergillus niger A9, Penicillium verricosum F4 and Geotrichum candidum G3. The third consortium had isolates listed as members of the first and second consortia A3, C1, A9, F4, and G3. Each isolate was grown in potato dextrose broth (PDB) at room temperature for 5 days. After incubation, the first consortium which had $\mathrm{A} 3$ and C1 was formed using $15 \mathrm{ml}\left(1.8 \times 10^{6}\right.$ spores $)$ of each isolate, for the second consortium which had three isolates, $10 \mathrm{ml}\left(1.2 \times 10^{6}\right.$ spores $)$ of each isolate was used while for the third consortium which had five isolates, $6 \mathrm{ml}\left(0.72 \times 10^{6}\right.$ spores $)$ of each isolate was used (Idowu and Ijah, 2017).

\section{Experimental Design and Treatment}

Completely randomized block design (CRBD) was used in this study. The bioremediation study was conducted according to the method of Baldrian et al., (2000) and was set up as follows: Two kilograms (2 kg) of soil moistened with 10\% distilled water (w/v) was weighed into two bowls and mixed thoroughly with diesel oil at 5\% and $10 \%$ respectively. The fungal consortium was inoculated and exposed to the air. Two controls were set up; the first control had soil with diesel oil, while the second control had soil only. All the 
experiments were set up in duplicates and sampling was done every two weeks for total duration of 12 weeks. The following parameters were monitored:

\section{Microbiological Analysis}

Aerobic heterotrophic bacteria and fungi in the soil samples were enumerated using nutrient agar (NA) and Sabouraud dextrose agar (SDA) respectively. Diesel-utilizing fungi were enumerated using diesel oil agar (DOA) while diesel utilizing bacteria were enumerated on mineral salts medium of Zajic and Supplisson (1972) supplemented with $28 \mathrm{~g} / \mathrm{l}$ of agar and $1 \%$ $(\mathrm{v} / \mathrm{v})$ diesel oil. Bacterial isolates obtained were characterized based on Gram's reaction and biochemical tests. The biochemical tests included production of coagulase, catalase, indole, motility test, citrate reduction and utilization of various carbohydrates such as glucose, lactose, fructose, and sucrose. The isolates were identified by comparing their characteristics with those of known taxa, as described by Buchanan and Gibbons (1974) in Bergey's Manual of Determinative Bacteriology. Fungal isolates were identified using the scheme of Alexopolus et al., (1996).

Characterization and Identification of Isolates

Fungal isolates were characterized based on microscopic and macroscopic appearances such as pigmentation, color of aerial and substrate hyphae, type of hyphae, shape and kind of asexual spore, presence of special structures such as foot cell, sporangiophore, or conidiophores, and the characteristic of the spore head (James \& Natalie, 2001). The fungal isolates were identified by comparing their characteristics with those of known taxa (Alexopolus et al., 1996).

\section{$\mathrm{pH}$ determination}

$\mathrm{pH}$ of soil was determined using $\mathrm{pH}$ meter (Testronic digital pH meter, Model 3505, Jenway,
United Kingdom). Five grammes of the soil sample was suspended in $25 \mathrm{ml}$ of distilled water and mixed well. The $\mathrm{pH}$ meter was standardized at $\mathrm{pH} 7.0$ using phosphate buffer solution after which the $\mathrm{pH}$ of the sample was determined in duplicates (Obire, 2012).

\section{Moisture determination}

The moisture content of the soil was determined using the dry weight method (Li and Mira 2010). A crucible was dried in an oven at $80{ }^{\circ} \mathrm{C}$ for few minutes, cooled in a desiccator and weighed $\left(\mathrm{W}_{1}\right)$. Ten grammes of the soil sample were placed in each crucible $\left(\mathrm{W}_{2}\right)$. The crucible and the sample were then dried in an oven at $105^{\circ} \mathrm{C}$ until constant weight was achieved. This was quickly transferred to a desiccator to cool and weighed quickly with minimal exposure to the atmosphere $\left(\mathrm{W}_{3}\right)$. The loss in weight of the sample during drying is the moisture content. It was calculated using the formula:

$\%$ Moisture content $=\underline{W_{3} W_{1}} \times 100$

Where $\mathrm{W}_{2} \mathrm{~W}_{1}$

$\mathrm{W}_{1}$ = Weight of the crucible without sample

$\mathrm{W}_{2}=$ Weight of the crucible + Weight of the sample before drying

$\mathrm{W}_{3}=$ Weight of the crucible + Weight of the sample after drying

\section{RESULTS AND DISCUSSION}

Microbial Counts in Remediated Soil

Aerobic Heterotrophic Bacterial Counts in Soil

The aerobic heterotrophic bacterial counts in unpolluted soil ranged from $5.0 \times 10^{6} \mathrm{cfu} / \mathrm{g}$ to 6.2 $\times 10^{6} \mathrm{cfu} / \mathrm{g}$ while that of $5 \%$ diesel oil contaminated soil ranged from $6.0 \times 10^{6} \mathrm{cfu} / \mathrm{g}$ to $7.8 \times 10^{6} \mathrm{cfu} / \mathrm{g}$ and soil contaminated with $10 \%$ diesel oil had aerobic heterotrophic bacterial counts ranging from $6.2 \times 10^{6} \mathrm{cfu} / \mathrm{g}$ to $7.6 \times 10^{6}$ 
$\mathrm{cfu} / \mathrm{g}$ after 12 weeks (Figure1 A, B). Aerobic heterotrophic bacterial counts of soil contaminated with 5\% diesel oil and remediated with fungal consortia (Aspergillus niger $\mathrm{A} 3+$ Aspergillus flavus C1) + oil + soil, (Aspergillus niger $\mathrm{A} 9+$ Penicillium verricosum $\mathrm{F} 4+$ Geotrichum candidum $\mathrm{G} 3)+$ oil + soil and (Aspergillus niger A3 + Aspergillus flavus $\mathrm{C} 1+$ Aspergillus niger A9 + Penicillium verricosum $\mathrm{F} 4+$ Geotrichum candidum G3) + oil + soil, decreased from $6.4 \times 10^{6} \mathrm{cfu} / \mathrm{g}$ to 2.1 $\times 10^{6} \mathrm{cfu} / \mathrm{g}, 6.7 \times 10^{6} \mathrm{cfu} / \mathrm{g}$ to $2.1 \times 10^{6} \mathrm{cfu} / \mathrm{g}$ and $5.9 \times 10^{6} \mathrm{cfu} / \mathrm{g}$ to $2.2 \times 10^{6} \mathrm{cfu} / \mathrm{g}$ respectively while that of the $10 \%$ diesel oil contaminated soil remediated with the fungal consortia (Aspergillus niger A3 + Aspergillus flavus C1) + oil + soil, (Aspergillus niger A9 + Penicillium verricosum $\mathrm{F} 4+$ Geotrichum candidum G3) + oil + soil and (Aspergillus niger A3 + Aspergillus flavus $\mathrm{C} 1+$ Aspergillus niger A9 + Penicillium verricosum $\mathrm{F} 4+$ Geotrichum candidum $\mathrm{G} 3)+$ oil + soil, decreased from $7.0 \times 10^{6} \mathrm{cfu} / \mathrm{g}$ to $2.2 \times 10^{6} \mathrm{cfu} / \mathrm{g}, 6.9 \times 10^{6} \mathrm{cfu} / \mathrm{g}$ to $2.1 \times 10^{6} \mathrm{cfu} / \mathrm{g}$ and $6.0 \times 10^{6}$ to $2.2 \times 10^{6} \mathrm{cfu} / \mathrm{g}$ respectively over the same period. It was observed that the counts of aerobic heterotrophic bacterial in unpolluted

A

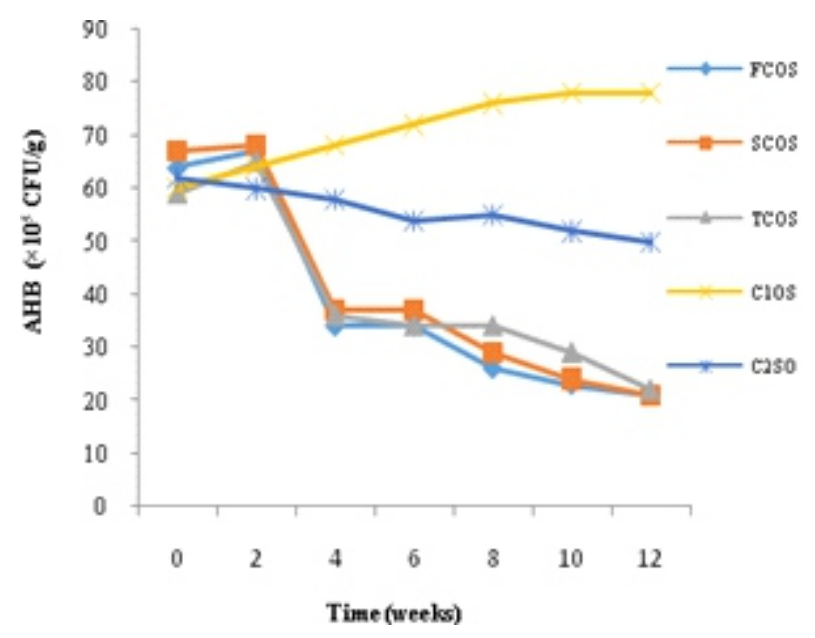

soil were lower compared to the counts in diesel oil (5 and 10\%) polluted soil (Figure1 A, B). This is probably due to the presence of diesel oil which served as a source of carbon and energy for the bacteria to grow. Aerobic heterotrophic bacterial counts in soil contaminated with 5 and $10 \%$ diesel oil remediated with the fungal consortia (Aspergillus niger A3 + Aspergillus flavus $\mathrm{C} 1)+\mathrm{oil}+$ soil, (Aspergillus niger A9 + Penicillium verricosum $\mathrm{F} 4$ + Geotrichum candidum G3) + oil + soil and (Aspergillus niger $\mathrm{A} 3+$ Aspergillus flavus $\mathrm{C} 1+$ Aspergillus niger A9 + Penicillium verricosum $\mathrm{F} 4+$ Geotrichum candidum G3) + oil + soil, were lower compared to the contaminated soil without bioaugmentation. There were no significant differences $(\mathrm{P}>0.05)$ among the three bioaugmentation treatments. This may be as a result of competition between the bacteria and fungi inoculated, because fungi have branching filamentous mode of growth which allows more efficient colonization of contaminated soil. This agrees with the findings of Adekunle and Adebambo (2009) who recorded similar results.

B

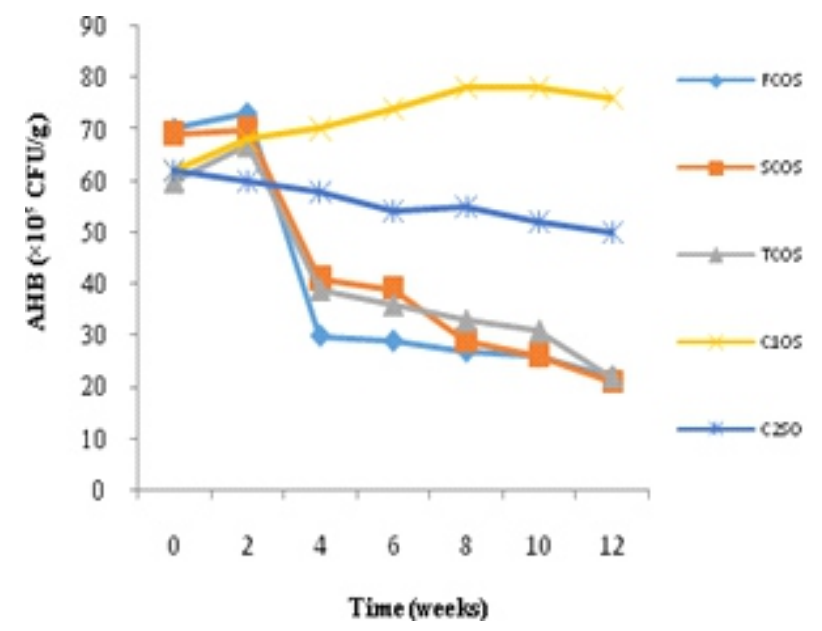

Figure 1: Aerobic heterotrophic bacterial (AHB) counts of diesel oil polluted soil remediated with fungal consortium: A (5\% diesel oil pollution), B (10\% diesel oil pollution).

FCOS (Aspergillus niger A3 + Aspergillus flavus C1) + oil + soil, SCOS (Aspergillus niger A9 + Penicillium verricosum F4 + Geotrichum candidum G3) + Oil + Soil, TCOS (Aspergillus niger A3 + Aspergillus flavus C1 + Aspergillus niger A9+ Penicillium verricosum F4 + Geotrichum candidum G3) + oil + soil, C1OS = Oil + Soil (Control 1), C2SO = soil only (Control 2) 


\section{Diesel-Utilizing Bacteria Counts in Soil}

The diesel utilizing bacterial counts of unpolluted soil ranged from $2.8 \times 10^{6} \mathrm{cfu} / \mathrm{g}$ to $3.6 \times 10^{6} \mathrm{cfu} / \mathrm{g}$ while that of the 5 and $10 \%$ diesel oil polluted soil ranged from $3.6 \times 10^{6} \mathrm{cfu} / \mathrm{g}$ to $5.8 \times 10^{6} \mathrm{cfu} / \mathrm{g}$ and $3.4 \times 10^{6} \mathrm{cfu} / \mathrm{g}-5.4 \times 10^{6} \mathrm{cfu} / \mathrm{g}$ respectively, after 12 weeks. Diesel utilizing bacterial counts of soil polluted with $5 \%$ diesel oil and remediated with the fungal consortia: (Aspergillus niger $\mathrm{A} 3+$ Aspergillus flavus $\mathrm{C} 1)+$ oil + soil, (Aspergillus niger $\mathrm{A} 9+$ Penicillium verricosum $\mathrm{F} 4+$ Geotrichum candidum G3) + oil + soil and (Aspergillus niger A3 + Aspergillus flavus $\mathrm{C} 1+$ Aspergillus niger A9 + Penicillium verricosum $\mathrm{F} 4+$ Geotrichum candidum $\mathrm{G} 3$ ) + oil + soil, decreased from $3.3 \times 10^{6} \mathrm{cfu} / \mathrm{g}$ to 1.8 $\times 10^{6} \mathrm{cfu} / \mathrm{g}, 3.4 \times 10^{6} \mathrm{cfu} / \mathrm{g}$ to $1.7 \times 10^{6} \mathrm{cfu} / \mathrm{g}$ and from $3.5 \times 10^{6} \mathrm{cfu} / \mathrm{g}$ to $1.8 \times 10^{6} \mathrm{cfu} / \mathrm{g}$ respectively over the same period (Figure $2 \mathrm{~A}$ ), while that of soil polluted with $10 \%$ diesel oil and remediated with the fungal consortia: (Aspergillus niger A3+ Aspergillus flavus C1) + oil + soil, (Aspergillus niger A9 + Penicillium verricosum $\mathrm{F} 4+$

A

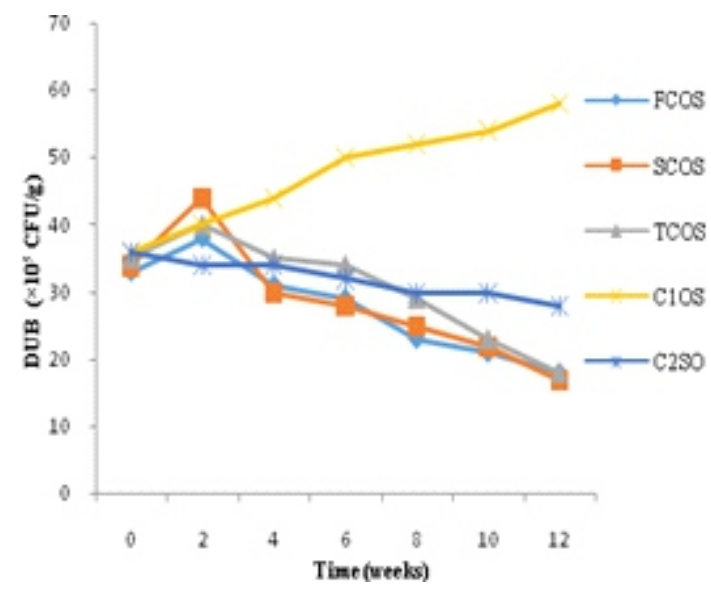

Geotrichum candidum G3) + oil + soil and (Aspergillus niger A3 + Aspergillus flavus $\mathrm{C} 1+$ Aspergillus niger $\mathrm{A} 9+$ Penicillium verricosum $\mathrm{F} 4+$ Geotrichum candidum G3) + oil + soil, decreased from $3.4 \times 10^{6} \mathrm{cfu} / \mathrm{g}$ to $1.8 \times 10^{6} \mathrm{cfu} / \mathrm{g}, 3.0 \times 10^{6} \mathrm{cfu} / \mathrm{g}$ to $1.9 \times 10^{6} \mathrm{cfu} / \mathrm{g}$ and from $3.1 \times 10^{6} \mathrm{cfu} / \mathrm{g}$ to $1.7 \times 10^{6} \mathrm{cfu} / \mathrm{g}$ respectively (Figure $2 \mathrm{~B}$ ). These results indicated higher counts of diesel utilizing bacterial in diesel oil polluted soil compared to unpolluted soil. This may be as a result of the presence of the diesel oil which served as carbon and energy source. There was lower diesel utilizing bacterial counts in the three bioaugumentation treatments compared to both unpolluted and polluted soil. However, no significant differences $(\mathrm{P}>0.05)$ existed among the three treatments. This might be due to competition between the resident microorganisms and fungi inoculated (Farid, 2012). It might also be due to the acidic nature of the soil which supported the growth of fungi more than bacteria (Hamman, 2004; Al-Nasrawi, 2012).

B

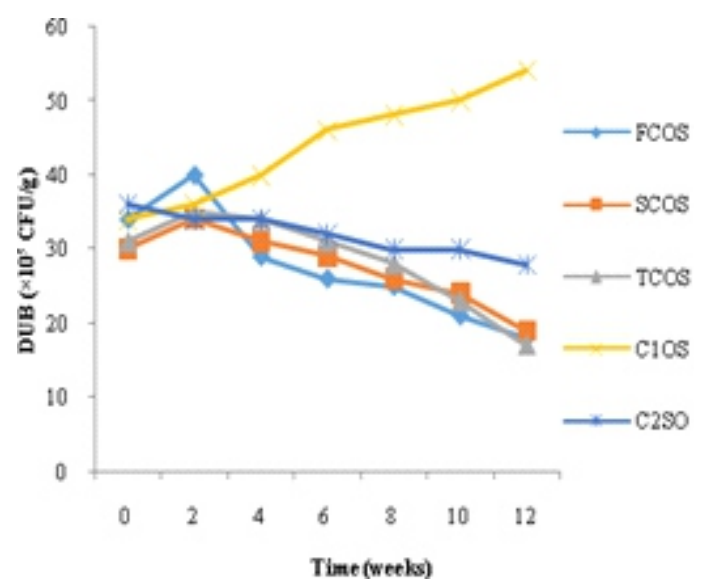

Figure 2: Diesel oil utilizing bacterial counts of diesel oil polluted soil remediated with fungal consortium: A (5\% diesel oil pollution), B (10\% diesel oil pollution). FCOS (Aspergillus niger A3+ Aspergillus flavus C1) + oil + soil, SCOS (Aspergillus niger A9 + Penicillium verricosum F4 + Geotrichum candidum G3) + oil + soil, TCOS (Aspergillus niger A3 + Aspergillus flavus C1 + Aspergillus niger A9+ Penicillium verricosum F4 + Geotrichum candidum G3) + oil + soil, C1OS = Oil + Soil (Control 1), C2SO = Soil Only (Control 2).

\section{Total Fungal Counts in Soil}

The total fungal counts of unpolluted soil ranged from $5.2 \times 10^{4} \mathrm{cfu} / \mathrm{g}$ to $6.4 \times 10^{4} \mathrm{cfu} / \mathrm{g}$ while that of $5 \%$ and $10 \%$ diesel oil contaminated soil ranged from $6.0 \times 10^{4} \mathrm{cfu} / \mathrm{g}$ to $8.8 \times 10^{4} \mathrm{cfu} / \mathrm{g}$ and $6.0 \times 10^{4} \mathrm{cfu} / \mathrm{g}$ to $7.8 \times 10^{4} \mathrm{cfu} / \mathrm{g}$ respectively (Figure 3 A, B). After 12 weeks, total fungal counts of soil contaminated with $5 \%$ diesel oil and remediated with the fungal consortia: (Aspergillus niger A3 + Aspergillus flavus C1) + oil + soil, (Aspergillus niger A9 + Penicillium verricosum $\mathrm{F} 4+$ Geotrichum candidum G3) + oil + soil and (Aspergillus niger A3 + Aspergillusflavus $\mathrm{C} 1+$ Aspergillus niger A9 + Penicillium verricosum $\mathrm{F} 4+$ Geotrichum candidum G3) + oil + soil, ranged from $6.7 \times 10^{4} \mathrm{cfu} / \mathrm{g}$ to 1.1 $\times 10^{5} \mathrm{cfu} / \mathrm{g}, 6.3 \times 10^{4} \mathrm{cfu} / \mathrm{g}$ to- $1.0 \times 10^{5} \mathrm{cfu} / \mathrm{g}$ and 
$6.7 \times 10^{4} \mathrm{cfu} / \mathrm{g}$ to- $1.1 \times 10^{5} \mathrm{cfu} / \mathrm{g}$ respectively. Soil polluted with $10 \%$ diesel oil and remediated with the fungal consortia: (Aspergillus niger A3 + Aspergillus flavus C1) + oil + soil, (Aspergillus niger A9 + Penicillium verricosum $\mathrm{F} 4+$ Geotrichum candidum $\mathrm{G} 3)+$ oil + soil and (Aspergillus niger A3 + Aspergillus flavus $\mathrm{C} 1+$ Aspergillus niger A9 + Penicillium verricosum $\mathrm{F} 4+$ Geotrichum candidum G3) + oil + soil, ranged from $6.5 \times 10^{4} \mathrm{cfu} / \mathrm{g}$ to $1.0 \times$ $10^{5} \mathrm{cfu} / \mathrm{g}, 6.5 \times 10^{4} \mathrm{cfu} / \mathrm{g}$ to- $1.1 \times 10^{5} \mathrm{cfu} / \mathrm{g}$ and $6.3 \times 10^{4} \mathrm{cfu} / \mathrm{g}$ to- $1.1 \times 10^{5} \mathrm{cfu} / \mathrm{g}$ respectively

A

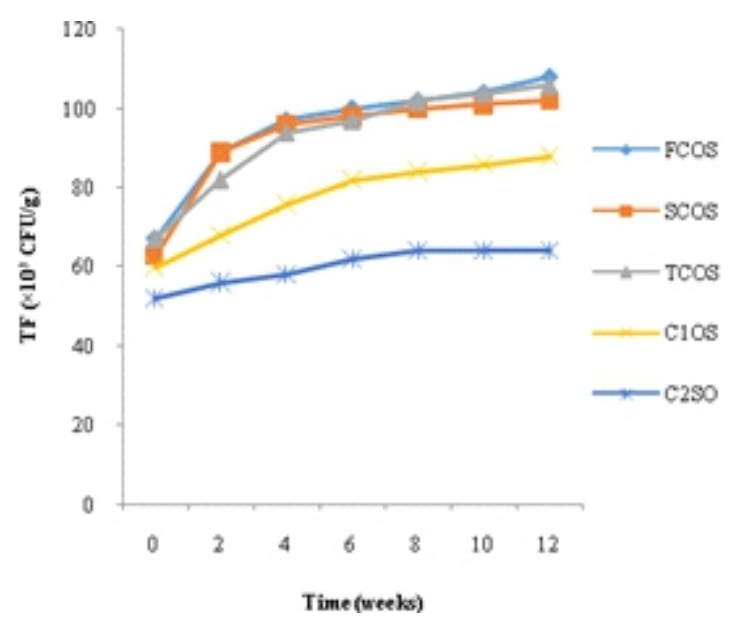

after 12 weeks (Figure $3 \mathrm{~A}, \mathrm{~B}$ ). It was observed that the total fungal counts of the contaminated soil were higher than that of the uncontaminated soil. This might be due to the ability of the fungi to utilize diesel oil as a source of energy and carbon. There were however, no significant differences $(\mathrm{P}$ $>0.05$ ) among the three bioaugumentation treatments. These results agree with the findings of Hamman (2004) who recorded higher counts of fungi in crude oil contaminated soil than uncontaminated soil.

$\mathrm{B}$

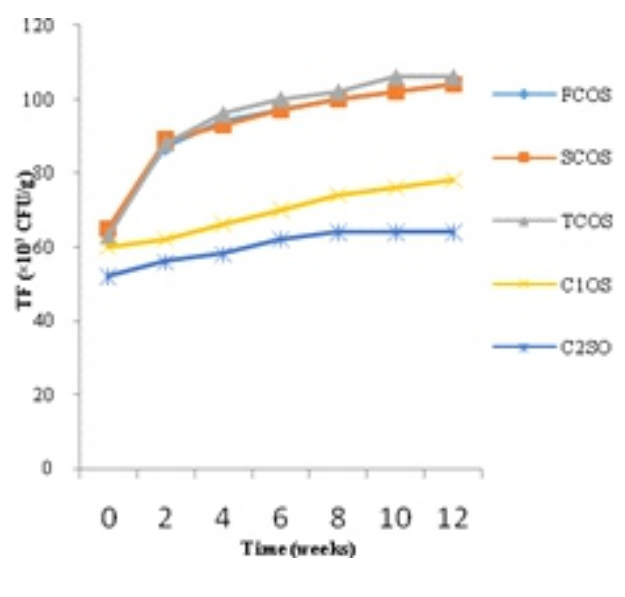

Figure 3: Total fungal counts (TFC) of diesel oil-polluted soil remediated with fungal consortium, A (5\% diesel oil pollution) and $\mathrm{B}(10 \%$ diesel oil pollution).

FCOS (Aspergillus niger A3+ Aspergillus flavus C1) + oil + soil, SCOS (Aspergillus niger A9 + Penicillium verricosum F4 + Geotrichum candidum G3) + oil + soil, TCOS (Aspergillus niger A3 + Aspergillus flavus $\mathrm{C} 1+$ Aspergillus niger A9+ Penicillium verricosum $\mathrm{F} 4+$ Geotrichum candidum G3) + oil + soil, C1OS = Oil + Soil (Control 1), C2SO = Soil Only (Control 2).

\section{Diesel-Utilizing Fungal Counts}

The diesel utilizing fungal counts of unpolluted soil ranged from $4.0 \times 10^{4} \mathrm{cfu} / \mathrm{g}$ to $5.6 \times 10^{4} \mathrm{cfu} / \mathrm{g}$ while that of 5 and $10 \%$ diesel oil polluted soil ranged from $5.4 \times 10^{4} \mathrm{cfu} / \mathrm{g}$ to $7.8 \times 10^{4} \mathrm{cfu} / \mathrm{g}$ and $5.2 \times 10^{4} \mathrm{cfu} / \mathrm{g}$ to- $8.8 \times 10^{4} \mathrm{cfu} / \mathrm{g}$ respectively after 12 weeks, (Figure 4 A, B). Diesel-utilizing fungal counts of soil polluted with $5 \%$ diesel oil and remediated with the fungal consortia: (Aspergillus niger A3 + Aspergillus flavus C1) + oil + soil, (Aspergillus niger A9 + Penicillium verricosum $\mathrm{F} 4$ + Geotrichum candidum G3) + oil + soil and (Aspergillus niger $\mathrm{A} 3+$ Aspergillus flavus $\mathrm{C} 1+$ Aspergillus niger A9 + Penicillium verricosum $\mathrm{F} 4+$ Geotrichum candidum G3) + oil + soil, ranged from $5.4 \times 10^{4} \mathrm{cfu} / \mathrm{g}$ to $1.1 \times 10^{5} \mathrm{cfu} / \mathrm{g}, 5.7 \times 10^{4} \mathrm{cfu} / \mathrm{g}$ to- $1.0 \times 10^{5} \mathrm{cfu} / \mathrm{g}$ and $5.7 \times 10^{4} \mathrm{cfu} / \mathrm{g}$ to- $1.0 \times 10^{5}$ cfu/g respectively. Soil polluted with $10 \%$ diesel oil and remediated with the fungal consortia: (Aspergillus niger $\mathrm{A} 3+$ Aspergillus flavus $\mathrm{C} 1)+\mathrm{oil}+$ soil, (Aspergillus niger A9 + Penicillium verricosum F4 + Geotrichum candidum G3) + oil + soil and (Aspergillus niger $\mathrm{A} 3+$ Aspergillus flavus $\mathrm{C} 1+$ Aspergillus niger $\mathrm{A} 9+$ Penicillium verricosum $\mathrm{F} 4+$ Geotrichum candidum G3) + oil + soil, ranged from $5.9 \times 10^{4} \mathrm{cfu} / \mathrm{g}$ to $1.0 \times 10^{5} \mathrm{cfu} / \mathrm{g}, 5.4 \times 10^{4} \mathrm{cfu} / \mathrm{g}$ to $1.0 \times 10^{5} \mathrm{cfu} / \mathrm{g}$ and $5.4 \times 10^{4} \mathrm{cfu} / \mathrm{g}$ to- $1.0 \times 10^{5}$ $\mathrm{cfu} / \mathrm{g}$ respectively after 12 weeks (Figure 4 A, B). These results showed lower diesel utilizing fungal counts in uncontaminated soil compared to contaminated soil probably, due to the presence of diesel oil which served as a source of carbon and energy for the fungi to proliferate. It may also be as a result of the acidic nature of the polluted soil which supported the growth of fungi. There were no significant differences $(\mathrm{P}>0.05)$ among the three soil treatments and the two oil concentrations in which there were high diesel utilizing fungal counts. This may be due to oxidoreductase activity, production of hydroxyl 
radicals and antibiotic compounds which could enable fungi to suppress the growth of bacteria or the ability of the inocula to increase the population of fungi in the soil. These results agree

A

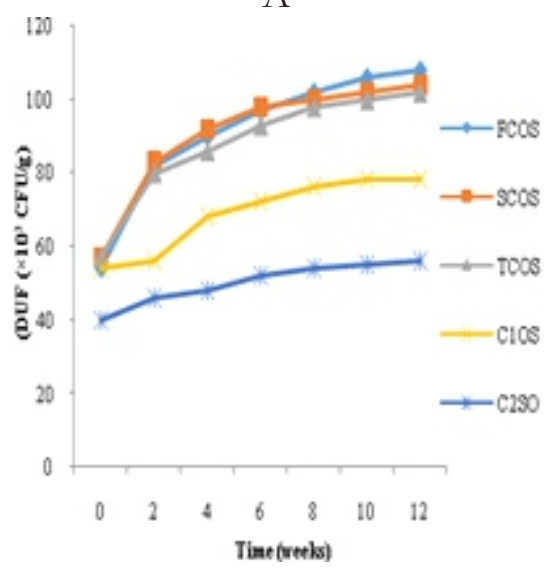

with the findings of Singh et al. (2011) who recorded high counts of fungi in crude oil polluted soil.
B

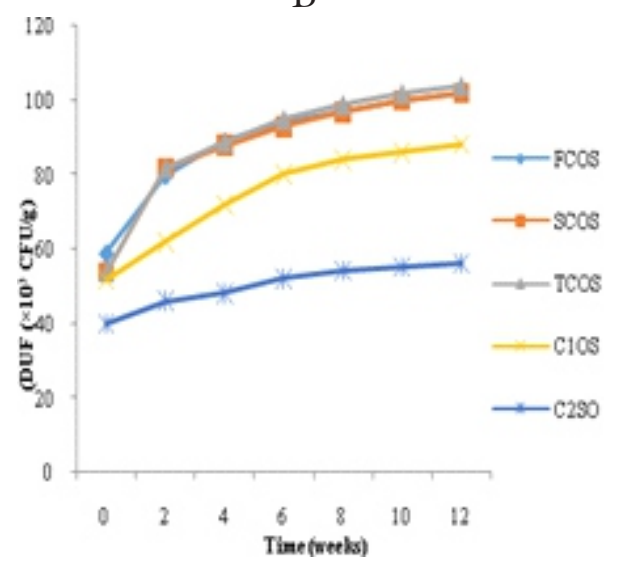

Figure 4: Diesel-utilizing fungal counts of diesel oil polluted soil remediated with fungal consortium, A (5\% diesel oil pollution) and $\mathrm{B}(10 \%$ diesel oil pollution).

FCOS (Aspergillus niger A3+ Aspergillusflawus C1) + oil + soil, SCOS (Aspergillus niger A9 + Penicillium verricosum F4 + Geotricbum candidum G3) + oil + soil, TCOS (Aspergillus niger A3 + Aspergillus flavus $\mathrm{C} 1+$ Aspergillus niger A9 + Penicillium verricosum $\mathrm{F} 4+$ Geotrichum candidum $\mathrm{G} 3)+$ oil + soil, $\mathrm{C} 1 \mathrm{OS}=$ Oil + Soil $($ Control 1), $\mathrm{C} 2 \mathrm{SO}=$ Soil Only $($ Control 2).

Identification and Frequency of Occurrence of Microbial Isolates in Remediated Soil

The bacterial isolates were identified as species of Pseudomonas, Bacillus, Micrococcus, Staphylococcus, and Escherichia. It was observed that species of Pseudomonas were more frequently isolated (31.58\%) followed by Bacillus and Micrococcus with frequency of occurrence of $21.05 \%$ each (Table
1). Staphylococcus had $15.79 \%$, while Escherichia had $10.53 \%$ frequency of occurrence. Species of Pseudomonas occurred most frequently probably due to high degradative capacity. Several authors have reported similar findings among which were Facundo et al., (2001), Jim et al., (2005) and Farid (2012).

Table 1: Frequency of Occurrence of Bacterial Isolates in Bioremediated Soil

\begin{tabular}{lcc}
\hline \multicolumn{1}{c}{ Organisms } & $\begin{array}{c}\text { Number of } \\
\text { isolates }\end{array}$ & \% Frequency of occurrence \\
\hline Pseudomonas aeruginosa & 6 & 31.58 \\
Bacillus subtilis & 4 & 21.05 \\
Micrococcus roseus & 4 & 21.05 \\
Staphylococcus aureus & 3 & 15.79 \\
Eschericbia coli & 2 & 10.53 \\
\hline \multicolumn{1}{c}{ Total } & 19 & 100 \\
\hline
\end{tabular}

Fungi were isolated and identified as species of Aspergillus, Scopuloropsis, Cephalosporium, Penicillium, Geotrichum, Mucor, Trichophyton, and Microsporum. Aspergillus niger occurred most frequently with $32.35 \%$ followed by Cephalosporium acremonium (14.71\%). Penicillium verrucosum, Geotrichum candidum and Mucor mucedo occurred at the same frequency $(11.76 \%)$ while Apergillus fumigatus had $5.88 \%$ frequency of occurrence.
Aspergillus flavus, Trichophyton soudanense and Microsporum gypseum had $2.94 \%$ frequency of occurrence each (Table 2). A. niger occurred most frequently, probably due to high degradative capacity and its wide spread distribution in the environment (Ijah, et al., (2013) and Agarry and Jimoda (2013) have implicated these fungi in hydrocarbon degradation. 
Table 2:Frequency of Occurrence of Fungal Isolates in Bioremediated Soil

\begin{tabular}{lcc}
\hline \multicolumn{1}{c}{ Organisms } & $\begin{array}{c}\text { Number of } \\
\text { isolates }\end{array}$ & \% Frequency of occurrence \\
\hline Aspergillus flavus & 1 & 2.94 \\
Aspergillus fumigatus & 2 & 5.88 \\
Aspergillus niger & 11 & 32.35 \\
Scopuloropsis Canadensis & 1 & 2.94 \\
Cephalosporium acremonium & 5 & 14.71 \\
Penicillium verricosum & 4 & 11.76 \\
Geotrichum candidum & 4 & 11.76 \\
Mucor mucedo & 4 & 11.76 \\
Trichophyton soudanense & 1 & 2.94 \\
Microsporum gypseum & 1 & 2.94 \\
\hline \multicolumn{1}{c}{ Total } & 34 & 100
\end{tabular}

\section{$\mathrm{pH}$ of Remediated Soil}

The $\mathrm{pH}$ of unpolluted soil ranged from 6.27 to 6.49 while that of 5 and $10 \%$ diesel oil polluted soil ranged from 5.01 to 5.20 and 5.07 - 5.27 respectively. $\mathrm{pH}$ of soil polluted with $5 \%$ diesel oil and remediated with the fungal consortia: (Aspergillus niger $\mathrm{A} 3+$ Aspergillus flavus $\mathrm{C} 1)+$ oil + soil, (Aspergillus niger A9 + Penicillium verricosum F4 + Geotrichum candidum G3) + oil + soil and (Aspergillus niger $\mathrm{A} 3+$ Aspergillus flavus $\mathrm{C} 1+$ Aspergillus niger A9 + Penicillium verricosum $\mathrm{F} 4+$ Geotrichum candidum G3) + oil + soil ranged from 5.34 to $6.07,5.52$ to- 6.07 and 5.21 to- 6.13 respectively (Table 3 ). That of soil polluted with $10 \%$ diesel oil and remediated with the fungal consortia (Aspergillus niger A3 + Aspergillus flavus C1) + oil + soil, (Aspergillus niger A9 + Penicillium verricosum $\mathrm{F} 4+$ Geotrichum candidum G3) + oil + soil and (Aspergillus niger $\mathrm{A} 3+$ Aspergillus flavus $\mathrm{C} 1+$ Aspergillus niger A9 + Penicillium verricosum $\mathrm{F} 4+$ Geotrichum candidum G3) + oil + soil ranged from 5.02 to $6.18,5.18$ to- 594 and 5.12 to- 5.95 respectively (Table 4). There were no significant differences $(\mathrm{P}>0.05)$ among the three bioaugmentation treatments and the two oil concentrations. The acidic metabolites produced by the microorganisms might have been responsible for the reduction in $\mathrm{pH}$ in diesel oil contaminated soil compared with uncontaminated soil. These findings are in agreement with the earlier findings by Hidayat et al., (2012) who reported that microbial utilization of hydrocarbon led to formation of organic acids.

Table 3: pH of Soil Polluted with 5\% Diesel Oil and Remediated with Fungal Consortium

\begin{tabular}{cccccc}
\hline $\begin{array}{c}\text { Time } \\
\text { (weeks) }\end{array}$ & FCOS & SCOS & TCOS & C1OS & C2SO \\
\hline 0 & $5.66 \pm 0.10^{\mathrm{d}}$ & $5.61 \pm 0.13^{\mathrm{d}}$ & $5.75 \pm 0.10^{\mathrm{c}}$ & $5.01 \pm 0.01^{\mathrm{g}}$ & $6.46 \pm 0.01^{\mathrm{b}}$ \\
2 & $6.07 \pm 0.02^{\mathrm{a}}$ & $6.06 \pm 0.02^{\mathrm{a}}$ & $6.13 \pm 0.01^{\mathrm{a}}$ & $5.02 \pm 0.00^{\mathrm{f}}$ & $6.31 \pm 0.04^{\mathrm{f}}$ \\
4 & $5.91 \pm 0.16^{\mathrm{b}}$ & $5.88 \pm 0.23^{\mathrm{b}}$ & $6.01 \pm 0.01^{\mathrm{b}}$ & $5.04 \pm 0.02^{\mathrm{e}}$ & $6.38 \pm 0.03^{\mathrm{e}}$ \\
6 & $5.84 \pm 0.19^{\mathrm{c}}$ & $5.75 \pm 0.27^{\mathrm{c}}$ & $5.66 \pm 0.20^{\mathrm{d}}$ & $5.07 \pm 0.01^{\mathrm{d}}$ & $6.49 \pm 0.01^{\mathrm{a}}$ \\
8 & $5.41 \pm 0.35^{\mathrm{e}}$ & $5.61 \pm 0.11^{\mathrm{d}}$ & $5.47 \pm 0.23^{\mathrm{e}}$ & $5.08 \pm 0.02^{\mathrm{c}}$ & $6.42 \pm 0.04^{\mathrm{d}}$ \\
10 & $5.36 \pm 0.01^{\mathrm{f}}$ & $5.58 \pm 0.12^{\mathrm{e}}$ & $5.25 \pm 0.02^{\mathrm{f}}$ & $5.11 \pm 0.01^{\mathrm{b}}$ & $6.45 \pm 0.03^{\mathrm{c}}$ \\
12 & $5.34 \pm 0.03^{\mathrm{g}}$ & $5.52 \pm 014^{\mathrm{f}}$ & $5.21 \pm 0.01^{\mathrm{g}}$ & $5.2 \pm 0.01^{\mathrm{a}}$ & $6.27 \pm 0.01^{\mathrm{g}}$ \\
\hline
\end{tabular}

Values are means \pm standard error of two replicates. Different superscripts in the same column indicate significant differences at $\mathrm{P}<0.05$.

FCOS (Aspergillus niger A3 + Aspergillus flavus C1) + oil + soil, SCOS (Aspergillus niger A9 + Penicillium verricosum F4 + Geotrichum candidum G3) + oil + soil, TCOS (Aspergillus niger A3 + Aspergillus flavus C1 + Aspergillus niger A9 + Penicillium verricosum F4 + Geotrichum candidum G3) + oil + soil, C1OS = Oil + Soil (Control 1), C2SO = Soil Only (Control 2). 
Table 4: pH of Soil Polluted with 10\% Diesel Oil and Remediated with Fungal Consortium

\begin{tabular}{|c|c|c|c|c|c|}
\hline $\begin{array}{c}\text { Time } \\
\text { (weeks) }\end{array}$ & FCOS & SCOS & TCOS & C1OS & $\mathrm{C} 2 \mathrm{SO}$ \\
\hline 0 & $5.52 \pm 0.06^{d}$ & $5.68 \pm 0.11^{b}$ & $5.64 \pm 0.02^{c}$ & $5.07 \pm 0.02^{g}$ & $6.46 \pm 0.01^{b}$ \\
\hline 2 & $6.18 \pm 0.03^{a}$ & $5.94 \pm 0.05^{a}$ & $5.95 \pm 0.03^{a}$ & $5.08 \pm 0.00^{\mathrm{f}}$ & $6.31 \pm 0.04^{f}$ \\
\hline 4 & $5.98 \pm 0.09^{b}$ & $5.56 \pm 0.03^{c}$ & $5.76 \pm 0.11^{b}$ & $5.09 \pm 0.01^{\mathrm{e}}$ & $6.38 \pm 0.03^{e}$ \\
\hline 6 & $5.70 \pm 0.08^{c}$ & $5.52 \pm 0.10^{\mathrm{d}}$ & $5.61 \pm 0.21^{\mathrm{d}}$ & $5.13 \pm 0.01^{\mathrm{d}}$ & $6.49 \pm 0.01^{a}$ \\
\hline 8 & $5.33 \pm 0.32^{\mathrm{e}}$ & $5.41 \pm 0.19^{\mathrm{e}}$ & $5.32 \pm 0.04^{\mathrm{e}}$ & $5.15 \pm 0.01^{\mathrm{c}}$ & $6.42 \pm 0.04^{d}$ \\
\hline 10 & $5.05 \pm 0.04^{f}$ & $5.19 \pm 0.07^{\mathrm{f}}$ & $5.17 \pm 0.05^{f}$ & $5.20 \pm 0.01^{b}$ & $6.45 \pm 0.03^{c}$ \\
\hline 12 & $5.02 \pm 0.01 \mathrm{~g}$ & $5.18 \pm 0.06^{g}$ & $5.12 \pm 0.02^{\mathrm{g}}$ & $5.27 \pm 0.02^{\mathrm{a}}$ & $6.27 \pm 0.01 \mathrm{~g}$ \\
\hline
\end{tabular}

Values are means \pm standard error of two replicates. Different superscripts in the same column indicate significant differences at $\mathrm{P}<0.05$.

FCOS (Aspergillus niger A3+ Aspergillus flavus $\mathrm{C} 1)+$ Oil + Soil, SCOS (Aspergillus niger A9 + Penicillium verricosum $\mathrm{F} 4+$ Geotrichum candidum G3) + Oil + Soil, TCOS (Aspergillus niger A3 + Aspergillus flawns $\mathrm{C}+$ Aspergillus niger A9+ Penicillium verricosum $\mathrm{F} 4+$ Geotrichum candidum $\mathrm{G} 3)+\mathrm{Oil}+$ Soil, $\mathrm{C} 1 \mathrm{OS}=\mathrm{Oil}+$ Soil (Control 1), $\mathrm{C} 2 \mathrm{SO}=$ Soil Only (Control 2).

\section{Moisture Content of Remediated Soil}

The moisture content of unpolluted soil ranged from 8.14 to $11.39 \%$ while that of 5 and $10 \%$ diesel oil-polluted soil ranged from 10.10 to $16.41 \%$ and $10.16-16.43 \%$ respectively. Moisture content of soil polluted with $5 \%$ diesel oil and remediated with the fungal consortia FCOS, SCOS and TCOS ranged from 10.09 to $16.42 \%$, $10.18-16.45 \%$ and $10.23-6.47 \%$ respectively (Table 5), while that of soil polluted with $10 \%$ diesel oil and remediated with fungal consortia FCOS, SCOS and TCOS ranged from 10.14 to
$16.30 \%, 10.20-16.35 \%$ and $10.15-16.54 \%$ respectively (Table 6). These results showed high moisture content in soil contaminated with diesel oil compared to soil without diesel oil contamination. There were no significant differences $(\mathrm{P}>0.05)$ among the three soil treatments and the two oil concentrations. This could be as a result of the contaminant's viscosity, which tended to increase the water holding capacity of the contaminated soil or may be due to the porosity of the uncontaminated soil (Collins, 2007).

Table 5: Moisture Content of Soil Polluted with 5\% Diesel Oil and Remediated with Fungal Consortium

\begin{tabular}{cccccc}
\hline $\begin{array}{c}\text { Time } \\
\text { (weeks) }\end{array}$ & FCOS & SCOS & TCOS & C1OS & C2SO \\
\hline 0 & $10.09 \pm 0.04^{\mathrm{g}}$ & $10.18 \pm 0.02^{\mathrm{f}}$ & $10.23 \pm 0.01^{\mathrm{g}}$ & $10.16 \pm 0.04^{\mathrm{f}}$ & $8.14 \pm 0.02^{\mathrm{f}}$ \\
2 & $10.20 \pm 0.02^{\mathrm{f}}$ & $10.22 \pm 0.02^{\mathrm{e}}$ & $10.25 \pm 0.01^{\mathrm{f}}$ & $10.10 \pm 0.01^{\mathrm{g}}$ & $8.17 \pm 0.03^{\mathrm{e}}$ \\
4 & $11.00 \pm 0.02^{\mathrm{e}}$ & $11.03 \pm 0.11^{\mathrm{g}}$ & $11.13 \pm 0.01^{\mathrm{e}}$ & $11.15 \pm 0.03^{\mathrm{e}}$ & $9.12 \pm 0.04^{\mathrm{g}}$ \\
6 & $15.90 \pm 0.02^{\mathrm{b}}$ & $15.87 \pm 0.02^{\mathrm{b}}$ & $15.79 \pm 0.07^{\mathrm{c}}$ & $15.82 \pm 0.04^{\mathrm{c}}$ & $10.71 \pm 0.06^{\mathrm{c}}$ \\
8 & $16.42 \pm 0.04^{\mathrm{a}}$ & $16.45 \pm 0.03^{\mathrm{a}}$ & $16.47 \pm 0.01^{\mathrm{a}}$ & $16.41 \pm 0.05^{\mathrm{a}}$ & $11.39 \pm 0.04^{\mathrm{a}}$ \\
10 & $15.57 \pm 0.09^{\mathrm{c}}$ & $15.30 \pm 0.02^{\mathrm{c}}$ & $16.04 \pm 0.02^{\mathrm{b}}$ & $16.06 \pm 0.02^{\mathrm{b}}$ & $10.57 \pm 0.09^{\mathrm{d}}$ \\
12 & $15.04 \pm 0.02^{\mathrm{d}}$ & $15.05 \pm 0.07^{\mathrm{d}}$ & $14.92 \pm 0.06^{\mathrm{d}}$ & $15.11 \pm 0.03^{\mathrm{d}}$ & $10.81 \pm 0.15^{\mathrm{b}}$ \\
\hline
\end{tabular}

Values are means \pm standard error of two replicates. Different superscripts in the same column indicate significant differences at $\mathrm{P}<0.05$.

FCOS (Aspergillus niger A3 + Aspergillus flavus C1) + oil + soil, SCOS (Aspergillus niger A9 + Penicillium verricosum F4 + Geotrichum candidum G3) + oil + soil, TCOS (Aspergillus niger A3 + Aspergillus flavus C1 + Aspergillus niger A9 + Penicillium verricosum F4 + Geotrichum candidum G3) + oil + soil, C1OS = Oil + Soil (Control 1), C2SO = Soil Only (Control 2). 
Table 6: Moisture Content of Soil Polluted with 10\% DieselOil and Remediated with Fungal Consortium

\begin{tabular}{cccccc}
\hline $\begin{array}{c}\text { Time } \\
\text { (weeks) }\end{array}$ & FCOS & SCOS & TCOS & C1OS & C2SO \\
\hline 0 & $10.16 \pm 0.02^{\mathrm{f}}$ & $10.20 \pm 0.02^{\mathrm{g}}$ & $10.15 \pm 0.03^{\mathrm{g}}$ & $10.16 \pm 0.02^{\mathrm{g}}$ & $8.14 \pm 0.02^{\mathrm{g}}$ \\
2 & $10.14 \pm 0.02^{\mathrm{g}}$ & $10.22 \pm 0.02^{\mathrm{f}}$ & $10.17 \pm 0.01^{\mathrm{f}}$ & $10.19 \pm 0.01^{\mathrm{f}}$ & $8.17 \pm 0.03^{\mathrm{f}}$ \\
4 & $11.09 \pm 0.03^{\mathrm{e}}$ & $11.13 \pm 0.05^{\mathrm{e}}$ & $11.12 \pm 0.10^{\mathrm{e}}$ & $11.07 \pm 0.01^{\mathrm{e}}$ & $9.12 \pm 0.04^{\mathrm{e}}$ \\
6 & $15.85 \pm 0.10^{\mathrm{b}}$ & $15.99 \pm 0.03^{\mathrm{b}}$ & $16.03 \pm 0.02^{\mathrm{b}}$ & $15.74 \pm 0.09^{\mathrm{b}}$ & $10.71 \pm 0.06^{\mathrm{c}}$ \\
8 & $16.30 \pm 0.02^{\mathrm{a}}$ & $16.35 \pm 0.03^{\mathrm{a}}$ & $16.54 \pm 0.08^{\mathrm{a}}$ & $16.43 \pm 0.05^{\mathrm{a}}$ & $11.39 \pm 0.04^{\mathrm{a}}$ \\
10 & $15.41 \pm 0.05^{\mathrm{c}}$ & $15.40 \pm 0.02^{\mathrm{c}}$ & $15.69 \pm 0.02^{\mathrm{c}}$ & $15.51 \pm 0.05^{\mathrm{c}}$ & $10.57 \pm 0.09^{\mathrm{d}}$ \\
12 & $14.89 \pm 0.07^{\mathrm{d}}$ & $15.18 \pm 0.04^{\mathrm{d}}$ & $15.05 \pm 0.03^{\mathrm{d}}$ & $14.94 \pm 0.09^{\mathrm{d}}$ & $10.81 \pm 0.15^{\mathrm{b}}$ \\
\hline
\end{tabular}

Values are means \pm standard error of two replicates. Different superscripts in the same column indicate significant differences at $\mathrm{P}<0.05$.

FCOS (Aspergillus niger A3+ Aspergillus flavus C1) + Oil + Soil, SCOS (Aspergillus niger A9 + Penicillium verricosum $\mathrm{F} 4+$ Geotrichum candidum G3) + Oil + Soil, TCOS (Aspergillus niger A3 + Aspergillus flavus $\mathrm{C} 1+$ Aspergillus niger A9+ Penicillium verricosum F4 + Geotrichum candidum G3) + Oil + Soil, C1OS = Oil + Soil (Control 1), C2SO = Soil Only (Control 2).

12

\section{O N C L U S I O N RECOMMENDATIONS}

This study showed the changes in the microbial populations in the bioremediation of diesel oilcontaminated soil in the shortest time possible. It also shows that the environment was conducive for the inoculants to remediate diesel oil in the soil. Microbial populations were higher in all treatments compared to the control and this resulted in the degradation of some hydrocarbons in the diesel oil. The microbes utilized the diesel oil as source of carbon and nitrogen to proliferate. Further studies should involve nutrient supplementation to the fungal inoculants for a faster bioremediation of oil polluted soil. The effects of temperature, $\mathrm{pH}$ and soil type on the effectiveness of the fungal consortia should be studied. The fungal consortia can be formed into commercial bioremediation agents.

\section{REFERENCES}

Abioye, P. O., Abdul Aziz, A. \& Agamuthu, P. (2010). Enhanced biodegradation of used engine oil in soil amended with organic wastes. Water, Air and Soil Pollution 209; 173-179.

Adekunle, A. A. \& Adebambo, O. A. (2009). Petroleum hydrocarbon utilization by fungi isolated from Detarium Senegalense (J. F Gmelin) seeds. Journal of American Science 3(1):69-76.
Agarry, S. E. \& Jimoda, L. A. (2013). Microbial degradation of phenol by polyurethane foam-immobilized cells of Psendomonas aeruginosa NCIB 950 and Psendomonas fluorescence NCIB 3756. Journal of International Environmental Applied Science 8(94): 563-572.

Alexopolus, C. J., Mims, C. W. \& Meredith, B. (1996). Introductory Mycology. John Wiley and sons. United Kingdom. 761-768.

AI-Nasrawi, H. (2012). Biodegradation of crude oil by fungi isolated from Gulf of México. Journal of Bioremediation and Biodegradation, 3 (4): 1-6.

Baldrian, P., Inderwiesche, C., Gabriel, J., Nerud, F. \& Zadrazil, F. (2000). Influence of cadmium and mecury on activities of ligninolytic enzymes and degradation of polycyclic aromatic hydrocarbon by Pleurotus ostreatus in soil. Applied and Environmental Microbiology 66(6): 24712478.

Buchanan, R. E. \& Gibbons, N. E. (1974). Bergey's Manual of Determinative Bacteriology, $8^{\text {th }}$ ed., Williams and Wilkins Co., Baltimore.

Bushnell, L. D. \& Hass, H. F. (1941). The utilization of certain hydrocarbons by microorganisms. Journal of Bacteriology 41, 653-673.

Collins, C. (2007). Implementing phytoremediation of petroleum hydrocarbons, Methods in Biotechnology 23, 
99-108.

Facundo, J. M., Vanessa, H. \& Teresa, M. L. (2001).Biodegradation of diesel oil in soil by a microbial consortium. Water, Air and Soil Pollution 128, 313-320.

Farid, W. A. (2012). Bioremediation of oil contaminated oil by axenic and mixed cultures of bacteria and fungi. Journal of AL-Taqani, 25 (2): 1-16.

Hamman, S. (2004). Bioremediation capabilities of white rot fungi. B 1570-Review Article. Methods in Biotechnology 20(23): 1-12.

Hidayat, A., Sanro, T. \& Itoh, K. (2012). Determination of chrysene degradation under saline conditions by Fusarium sp. F092, a fungus screened from nature. Journal of FungalBiology. 116 (6): 706-714.

Idowu, F.C., and Ijah, U. J. J. (2017). Bioremediation of diesel oil contaminated soil following amendment with fungal consortium. Journal of science, technology, mathematics and education (JOSTMED), 13(3):16-26

Ijah, U. J. J., Auta, S. H. \& Olanrewaju, R. K. (2013). Biostimulation of crude oil contaminated soil using soybean waste. African Scientific Publisher, 1, 285-291.

Ijah, U. J. J. \& Antai, S. P. (2003).The potential use of chicken-drop microorganisms for oil spill remediation. The Environmentalist 23, 89-95.

James, G. C. \& Natalie, S. (2001). Microbiology. $A$
Laboratory Manual. University Press Publishing House, University of Ibadan, pg. 211-223.

Jim, C. P., Selina, M. B., Singleton, I. \& Atlas, R. M. (2005). Environmental pollution and restoration. A role for bioremediation. In: Bioremediation: Applied Microbiology, ASM Press, Washington, DC, pg. 1-5.

Li, E. \& Mira de Orduna, R. (2010). A rapid method for the determination of microbial biomass by dry weight using a moisture analyser with an infrared heating source and an analytical balance. Letters in Applied Microbiology 50, 283-288.

Norton, M. J. (2012). Fungi for bioremediation of hydrocarbon pollutants. Hohonu, 10, 1-21

Obire, O. (2012). Studies on the biodegradation potentials of some microorganisms isolated from water systems of two petroleum producing area in Nigeria. Nigerian Journal of Botany, 1, 81-90.

RHF (2012) Rose House Foundation -Used oilused lubricating oil is hazardous. Rose House Foundation.org. za.

Singh, A., Parmar, N. \& Ramesh, C. K. (2011). Bioaugumentation, Biostimulation and Biocontrol. Springer - Verlag, Berlin, Heidelberg, Germany, 78-98

Zajic, C. \&Supplisson, B. (1972).Emulsification and degradation of "bunker C" Fuel oil by microorganisms. Biotechnology Bioengineering 14,331-343. 